DOI: $10.14451 / 2.154 .39$

\title{
СООТНОШЕНИЕ ПРИНЦИПА УСТНОСТИ ГРАЖДАНСКОГО ПРОЦЕССА С УПРОЩЕННЫМ ПРОИЗВОДСТВОМ
}

\author{
(C) 2021 Лошкарев А. В. \\ кандидат юридических наук \\ Самарский государственный экономический университет, Россия, Самара \\ E-mail:2482337@mail.ru \\ (C) 2021 Брянцева В.А. \\ магистрант \\ Самарский государственный экономический университет, Россия, Самара \\ E-mail: bryantzeva.varvara@yandex.ru
}

Институт упрощенного производства в гражданском процессе появился относительно недавно в российской правовой системе, и остается одним из самых открытых для изучения его функционирования. Рассмотрение соотношения принципа устности гражданского процесса с упрощенным производством является весьма актуальным, так как упрощенное производство строится на принципе письменности. В данной статье рассматривается правовая позиция ЕСПЧ в области применения принципа письменности в рамках упрощенного процесса.

Ключевые слова: гражданский процесс, принцип устности, упрощенное производство, судебное разбирательство, ЕСПЧ, принцип письменности, доказательства.

В ст. 157 Гражданского процессуального кодекса РФ [2] (далее ГПК РФ) закреплены основные принципы судопроизводства - непосредственности, устности и непрерывности судебного разбирательства. Представленные принципы составляют принцип публичности судебного производства. Данный принцип закреплен в Европейской конвенции о защите прав человека и основных свобод [1]. Возникает вопрос о допустимости построения упрощенного процесса исключительно на основе принципа письменности и соотношении упрощенного производства с принципом устности, который является основной гарантией публичности судебного разбирательства.

Дела упрощенного судопроизводства в соответствии с гл. 21 ГПК РФ рассматриваются по общим правилам искового производства. Особенностью упрощенного судопроизводства является то, что предварительное судебное разбирательство не проводится, стороны не вызывают в суд в соответствии с ст. 232.3 ГПК РФ. В соответствии с законодательством РФ, суд обязан лишь известить стороны о рассмотрении дела в порядке упрощенного производства или о переходе на упрощенное производство. В процессе суд рассматривает только документарные доказательства и разъяснения сторон по делу.

Особенностью предоставления доказательств и дополнительных документов в упрощенном производстве является их предоставление в суд в 2 этапа с установлением фиксированных сроков со дня вынесения определения о принятии искового заявления к производству или определения о переходе к рассмотрению дела в порядке упрощенного производства:

- не менее пятнадцати дней для представления доказательств и возражений относительно предъявленных требований;

- не менее тридцати дней для представления дополнительных документов, содержащих объяснения по существу заявленных требований и возражений в обоснование своей позиции.

Документы, прилагаемые к исковому заявлению, подаются в суд по общим правилам. Таким образом, в рамках упрощенного производства нарушается принцип устности, который является основополагающим принципом судебного разбирательства.

Сочетание устности и письменности в процессуальной деятельности характерно для современного гражданского судопроизводства. Закономерным является вопрос о допустимых пределах применения принципа письменности в упрощенном производстве, а также его соотношения с принципом устности. Так, согласно с п. 9 информационного письма ВАС от 20 декабря 1999 г. [3] указывается на то, что ЕСПЧ признает 
принцип письменности при упрощенном производстве. ЕСПЧ ссылается на то, что спор может быть рассмотрен как в присутствии сторон, и заинтересованных лиц, так и без участия сторон.

В деле о «Варела Ассалино против Португалии» ЕСПЧ было вынесено решение о праве на устное разбирательство. Данный случай был связан с толкованием норм Гражданского кодекса, суд рассмотрел данное обращение в порядке упрощенного производства (применяя принцип письменности), стороны не были вызваны на судебное заседание. После этого В. Ассалино подал жалобу, требуя проведения публичного разбирательства (соблюдения принципа устности). Однако характер дел, подлежащих разрешению, не требовал проведения публичного рассмотрения. Суд счел фактические обстоятельства дела установленными, необходимо было только вынести решение по вопросам права в связи с толкованием Гражданского кодекса. Данный вывод нельзя признать необоснованным, так как в ходе производства по делу не возникло вопросов, которые нельзя было разрешить удовлетворительным образом путем рассмотрения письменных доказательств. Единственный спорный вопрос был связан с толкованием положений Гражданского кодекса. В случаях, когда разрешению подлежат только вопросы права, рассмотрение письменных заявлений является более целесообразным, чем прения сторон, и, возможно, рассмотрение дела на основе письменных доказательств является достаточным. Заявитель не представил в Европейский суд убедительных доказательств в пользу того, что для обеспечения справедливого разбирательства после обмена меморандумами необходимо было провести и прения сторон. Наконец, в определенных случаях власти вправе принимать во внимание и соображения эффективности и экономии. Например, как в данном случае, когда фактические обстоятельства не являются предметом спора, а вопросы права не представляют особой сложности, то обстоятельство, что публичное разбирательство дела не проводилось, не является нарушением норм права. Суд сослался на то, что фактические обстоятельства дела не требовали присутствия сторон, жалоба была отклонена.

Отметим, что применение принципа письменности является наиболее эффективным при рассмотрении фактических обстоятельств, которые не являются предметом спора. Принцип письменности применяется при рассмотрении не сложных дел, при этом не нарушая принципа публичного разбирательства.

В деле «Юссила против Финляндии» [4] ЕСПЧ занял достаточно интересную позицию в области применения принципа письменности. Финляндия в качестве стороны ответчика, просила рассмотреть данное дело в письменном виде, так как рассматривается фактический вопрос, а не предмет спора. ЕСПЧ представленную позицию поддержал, а также указал, что применение письменной процедуры рассмотрения дела дает возможность рассмотреть надлежащим образом материалы дела. Также ЕСПЧ подтвердил, что применение принципа письменности в рамках судебного процесса бывает порой эффективнее чем рассмотрение дела в рамках устного процесca.

Таким образом, письменное производство без устного пояснения сторон в ряде случаев не рассматривается ЕСПЧ как нарушение Конвенции о защите прав человека и основных свобод. Стоит отметить, что в данном случае российское процессуальное законодательство также согласно с позиций ЕСПЧ, ведь упрощенное производство основано на принципе письменности. Поэтому говорить о том, что в ходе упрощенного судопроизводства ущемляется принцип устного судебного разбирательства является не вполне обоснованным. Ведь применение принципа письменности в упрощённом производстве является способом снижения загруженности судов, что в свою очередь влияет на эффективность судебной системы в целом.

\section{Библиографический список}

1. Конвенция о защите прав человека и основных свобод (Заключена в г. Риме 04.11.1950) // Справочноправовая система «КонсультантПлюс».

2. Гражданский процессуальный кодекс Российской Федерации от 14.11.2002 № 138-Ф3 (ред. от 02.12.2019) (с изм. и доп., вступ. в силу с 30.03.2020) // Справочно-правовая система «КонсультантПлюс».

3. Информационное письмо ВАС РФ от 20.12.1999 № C1-7/СМП-1341 // Справочно-правовая система «КонсультантПлюс».

4. Постановление Европейского Суда по правам человека от 23 ноября 2006 г. Дело «Юссила против Финляндии» // Правовой портал ГАРАНТ.ру 